\title{
Diphtheria Toxin-Induced Cell Death Triggers Wnt-Dependent Hair Cell Regeneration in Neonatal Mice
}

\author{
Lingxiang Hu, ${ }^{1,2,3}$ Jingrong Lu, ${ }^{1,2,3}{ }^{-H a o}$ Chiang, ${ }^{2,3} \mathrm{Hao} \mathrm{Wu},{ }^{1}{ }^{\circledR}$ Albert S. B. Edge, ${ }^{2,3 *}$ and Fuxin Shi $\mathbf{i}^{2,3 *}$ \\ ${ }^{1}$ Ear Institute, Shanghai Key Laboratory of Translational Medicine on Ear and Nose Diseases, Department of Otolaryngology-Head and Neck Surgery, \\ Xinhua Hospital, Shanghai Jiaotong University School of Medicine, Shanghai, China, ${ }^{2}$ Department of Otology and Laryngology, Harvard Medical School,

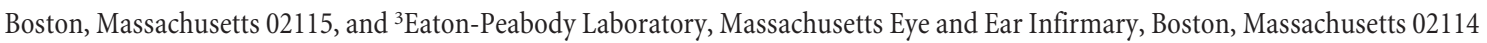

Cochlear hair cells (HCs), the sensory cells that respond to sound, do not regenerate after damage in adult mammals, and their loss is a major cause of deafness. Here we show that $\mathrm{HC}$ regeneration in newborn mouse ears occurred spontaneously when the original cells were ablated by treatment with diphtheria toxin (DT) in ears that had been engineered to overexpress the DT receptor, but was not detectable when HCs were ablated in vivo by the aminoglycoside antibiotic neomycin. A variety of Wnts (Wnt1, Wnt2, Wnt2b, Wnt4, Wnt5a, Wnt7b, Wnt9a, Wnt9b, and Wnt11) and Wnt pathway component Krm2 were upregulated after DT damage. Nuclear $\beta$-catenin was upregulated in HCs and supporting cells of the DT-damaged cochlea. Pharmacological inhibition of Wnt decreased spontaneous regeneration, confirming a role of Wnt signaling in HC regeneration. Inhibition of Notch signaling further potentiated supporting cell proliferation and HC differentiation that occurred spontaneously. The absence of new HCs in the neomycin ears was correlated to less robust Wnt pathway activation, but the ears subjected to neomycin treatment nonetheless showed increased cell division and HC differentiation after subsequent forced upregulation of $\beta$-catenin. These studies suggest, first, that Wnt signaling plays a key role in regeneration, and, second, that the outcome of a regenerative response to damage in the newborn cochlea is determined by reaching a threshold level of Wnt signaling rather than its complete absence or presence.

Key words: apoptosis; hair cell; necrosis; regeneration; Wnt

Significance Statement

Sensory HCs of the inner ear do not regenerate in the adult, and their loss is a major cause of deafness. We found that HCs regenerated spontaneously in the newborn mouse after diphtheria toxin (DT)-induced, but not neomycin-induced, HC death. Regeneration depended on activation of Wnt signaling, and regeneration in DT-treated ears correlated to a higher level of Wnt activation than occurred in nonregenerating neomycin-treated ears. This is significant because insufficient regeneration caused by a failure to reach a threshold level of signaling, if true in the adult, has the potential to be exploited for development of clinical approaches for the treatment of deafness caused by HC loss.

\section{Introduction}

The sensory HCs that detect sound and transmit their signal to the brain via the auditory nerve are susceptible to damage. The

Received June 26, 2015; revised July 18, 2016; accepted July 20, 2016.

Author contributions: H.C., A.S.B.E., and F.S. designed research; L.H., J.L., H.C., and F.S. performed research; L.H., H.C., H.W., A.S.B.E., and F.S. analyzed data; H.W., A.S.B.E., and F.S. wrote the paper.

This work was supported by National Natural Science Foundation of China Grant 81300821; Science and Technology Commission of Shanghai Municipality Grant 14DZ2260300; the Hearing Restoration Project of the Hearing Health Foundation; NIH NIDCD Grants R01007174, P30 DC05209, and R03 DC010270; the Shulsky Foundation; David H. Koch; and Robert Boucai.

${ }^{*}$ A.S.B.E. and F.S. contributed equally to this work.

The authors declare no competing financial interests.

Correspondence should be addressed to either of the following: Albert S. B. Edge, Eaton-Peabody Laboratory, Harvard Medical School, Massachusetts Eye and Ear Infirmary, 243 Charles Street, Boston, MA 02114, E-mail: albert_edge@meei.harvard.edu; or Hao Wu, Department of Otolaryngology-Head and Neck Surgery, Xinhua Hospital, Ear Institute, Shanghai Jiaotong University School of Medicine, Shanghai, China. E-mail:wuha0622@sina.cn. sensory nervous system evolved with high degree of specialization but with a decreased ability to regenerate compared to lower species, and loss of sensory HCs is a major cause of deafness. HC damage is typically caused by noise exposure, ototoxic drugs, infections, and aging, and the lack of a regenerative response to replace the cells in the cochlea, the mammalian hearing organ, leads to a high prevalence of acquired forms of deafness, particularly in older adults, with an incidence above age 65 greater then $50 \%$.

In the newborn mouse cochlea, supporting cells have the capacity to generate significant numbers of new HCs with inhibition of Notch after damage in vitro (Doetzlhofer et al., 2009; Korrapati et al., 2013; Bramhall et al., 2014; Cox et al., 2014). We 
and others have observed spontaneous regeneration of HCs in models of HC loss in the newborn mouse (Bramhall et al., 2014; Cox et al., 2014). The yield of HCs increased after Notch inhibition (Bramhall et al., 2014), suggesting that pathways of regeneration may be activated, but not sufficient to fully regenerate the organ. The increase in HC number was muted when Wnt signaling was inhibited (Bramhall et al., 2014). Wnts are released after damage in invertebrates and lower vertebrates as a crucial part of the damage response (Kawakami et al., 2006; Chai et al., 2012; Sun and Irvine, 2014). Mechanisms of regeneration in the adult often involve the use of pathways that served to generate the cells in the embryo. In the chick ear, loss of HCs is followed immediately by supporting cell division and transdifferentiation (Bermingham-McDonogh and Rubel, 2003; Cafaro et al., 2007; Daudet et al., 2009). In the present study, we find differences in the newborn mammalian cochlea in the extent of release of Wnts in response to damage induced by diphtheria toxin (DT) versus neomycin, suggesting a conservation of pathways used to drive regeneration. Moreover, the extent of Wnt activation correlates with the regenerative response seen after DT- but not neomycininduced HC death.

\section{Materials and Methods}

Animals. Induced-DTR (iDTR) mice, which contain a loxP-flanked stop sequence upstream of the DT receptor (DTR) at the Rosa26 locus, were obtained from The Jackson Laboratory (Stock 007900; Buch et al., 2005). $\beta$-catenin ${ }^{\text {flox(exon3) }}$ mice (Harada et al., 1999) were generously provided by M. Taketo (Kyoto University, Kyoto, Japan), Sox2-Cre-ER mice (Arnold et al., 2011) by K. Hochedlinger (Harvard Medical School, Boston, MA), and Gfi1-Cre mice (Yang et al., 2010) by L. Gan (University of Rochester, Rochester, NY). Rosa26 reporter mice, containing a loxPflanked stop cassette upstream of a red fluorescent protein variant (Stock 007914; Madisen et al., 2010), were obtained from The Jackson Laboratory. All animal experiments were approved by the Institutional Animal Care and Use Committee of the Massachusetts Eye and Ear Infirmary.

$H C$ death in iDTR mice. iDTR mice crossed with Gfil-Cre mice received $100 \mathrm{ng}$ of DT at postnatal day 1 (P1), P4, or P6, once a day for $3 \mathrm{~d}$ via intraperitoneal injection. Mice of either sex were used for all experiments. Mouse pups were killed $4 \mathrm{~d}$ later. iDTR, Gfil-Cre, and wild-type littermates were used as controls for iDTR;Gfil-Cre mice. No differences were seen among the controls, and representative data with iDTR are therefore shown.

Intracochlear delivery of neomycin or Wnt inhibitor. P1 mice were anesthetized by lowering body temperature for the surgical procedure. A postauricular incision was made on the left side, and the bulla was lifted to expose the cochlea. Neomycin (200 $\mathrm{nl}$ of a $50 \mathrm{~mm}$ solution) or Wnt inhibitor, IWP-2 $(10 \mu \mathrm{M}, 200 \mathrm{nl})$, was injected through the cochlear capsule into scala media at the cochear basal turn with a glass pipette (end diameter, $5 \mu \mathrm{m}$ ) attached to a nanoliter micropump (WPI, UMP3 + Micro4 + NanoFil) at $60 \mathrm{nl} / \mathrm{min}$. After injection, the incision was sutured and the mice were brought to a heating pad to recover. Tissue was analyzed after $4 \mathrm{~d}$.

Constitutive expression of $\beta$-catenin in vivo. Sox2-Cre-ER mice were mated with $\beta$-catenin $n^{\text {flox(exon } 3)}$ mice. After intracochlear injection of neomycin at P1, tamoxifen dissolved in corn oil $(100 \mu \mathrm{l}$ at $50 \mathrm{mg} / \mathrm{ml})$ was given to the mothers of the compound transgenic mice and passed to the pups via the milk to generate the $\beta$-catenin ${ }^{\Delta \text { exon } 3}$ mice. Pups were killed at P5. Pups were genotyped for both Cre and $\beta$-catenin ${ }^{\text {flox(exon3) }}$.

In vivo labeling of HCs with FM1-43. One day before being killed, mice were injected on the back, subcutaneously ( $3 \mathrm{mg} / \mathrm{kg}$ body weight), with FM1-43 (Meyers et al., 2003). After fixing with 4\% paraformaldehyde (PFA) for $20 \mathrm{~min}$, FM1-43 uptake in HCs was examined by confocal microscopy.

Labeling necrotic cells with propidium iodide. Organs of Corti, freshly dissected from neonatal mice with fixation, were incubated with propidium iodide at $1.5 \mu \mathrm{M}$ for $5 \mathrm{~min}$ at room temperature. Organs of Corti were washed three times with PBS buffer, fixed, and immunostained.
Labeling apoptotic cells with annexin $V$. The organ of Corti was stained with annexin V (PromoKine, catalog \#PK-CA707-30017) 30 min after neomycin injection, $1 \mathrm{~d}$ after DT damage, or without treatment. In brief, the organ of Corti was incubated with FITC-annexin V and Hoechst solution for $15 \mathrm{~min}$ in the dark, and then immediately scanned with a confocal microscope.

Cell proliferation. To label dividing cells in vivo, $10 \mu$ l 5-ethynyl-2'deoxyuridine (EdU, $10 \mathrm{mg} / \mathrm{ml}$ ) was given to the pups by subcutaneous injection, twice a day for 4 continuous days. Incorporated EdU was detected with Alexa Fluor azide using Click-iT EdU Image kits (Invitrogen) according to the manufacturer's protocol, before immunostaining.

$R T$-PCR. Total RNA was extracted from isolated organs of Corti using the RNeasy Mini kit (Qiagen); cDNA was synthesized from RNA $(1 \mu \mathrm{g})$ with SuperTranscipt III (New England Biolabs). Quantitative PCR was performed for 45 cycles, and GAPDH was used as an internal control in a PerkinElmer ABI PRISM 7700 Sequence Detector (Applied Biosystems). Wnt ligands were analyzed using SYBER Green (ThermoFisher). All other analysis was performed with Taqman probes (Applied Biosystems). Genes with signals occurring later than 45 cycles were considered undetectable. The organs of Corti were harvested and analyzed 1 and $4 \mathrm{~d}$ after neomycin or DT injection.

Notch inhibition. The organs of Corti from iDTR;Gfil-Cre mice that had received two doses of DT were dissected and cultured for $12 \mathrm{~h}$ before treatment. Organs of Corti were treated with $5 \mu \mathrm{M}$ dibenzazepine (desphydroxy; LY411575; Santa Cruz Biotechnology) for $3 \mathrm{~d}$ and compared to controls given $0.1 \%$ dimethyl sulfoxide.

Histology and immunostaining. Cochleae were dissected and immediately fixed for $20 \mathrm{~min}$ with $4 \%$ PFA (Electron Microscopy Sciences). The organ of Corti was separated from the stria vascularis and fixed further in $4 \%$ PFA for $30 \mathrm{~min}$.

Antibodies used in this study were against myosin VIIa (1:800; Proteus), Sox2 (1:500; Santa Cruz Biotechnology), Ki67 (1:100; ThermoFisher), cleaved caspase-3 (1:200; Cell Signaling Technology), and transcriptionally active $\beta$-catenin (PY489 $\beta$-catenin; Developmental Studies Hybridoma Bank). Species-specific Alexa Fluor-conjugated secondary antibodies were used for detection (1:500; Invitrogen).

Whole-mount preparations of the organ of Corti were analyzed using a Leica TCS SP 5 confocal microscopy. The organ of Corti was scanned in the $Z$ plane followed by the $Y$ plane at the indicated $X Z$ line.

Cell counting. Confocal $Z$ stacks of the entire cochlear whole mount were projected into a single image to capture all cells from different planes of focus for counting. This method allowed us to distinguish between inner HCs (IHCs) and outer HCs (OHCs). Atoh1- or myosin VIIa-positive HCs in the pillar cell region were manually counted with Image J software (NIH) from the entire cochlear whole mount. Cell counts for the $\beta$-catenin-expressing group were compared to those for littermates without $\beta$-catenin overexpression and were analyzed by Student's $t$ test.

\section{Results}

\section{Death of HCs induced by DT}

Mice with the DTR inserted after a loxP-flanked stop sequence become susceptible to cell ablation after Cre recombination and exposure to DT and are thus termed induced-DTR mice (Buch et al., 2005). Gfil is expressed in auditory HCs from E15.5 through adulthood (Yang et al., 2010). DT was given at $\mathrm{P} 1$, and the cochlea was harvested at P4 from iDTR;Gfil-Cre mice, in which Cre is driven by Gfil. No HC damage was observed after DT treatment of iDTR mice without Gfi1-Cre and their wild-type littermates (Fig. $1 A, B$ ). Examination of the organ of Corti showed successful HC targeting in iDTR; Gfil-Cre mice without gross structural changes to the organ of Corti (myosin VIIa-positive cells, Fig. $1 B, C$ ). HC death was most evident in the apical region, and the remaining $\mathrm{HCs}$, although myosin VIIa positive, had lost the ability to take up HC transduction channel dye, FM1-43 (Fig. 1C). Loss of uptake of FM1-43 was more pronounced than outright cell death and occurred in an apex-to-base gradient (Fig. 1D,E). 

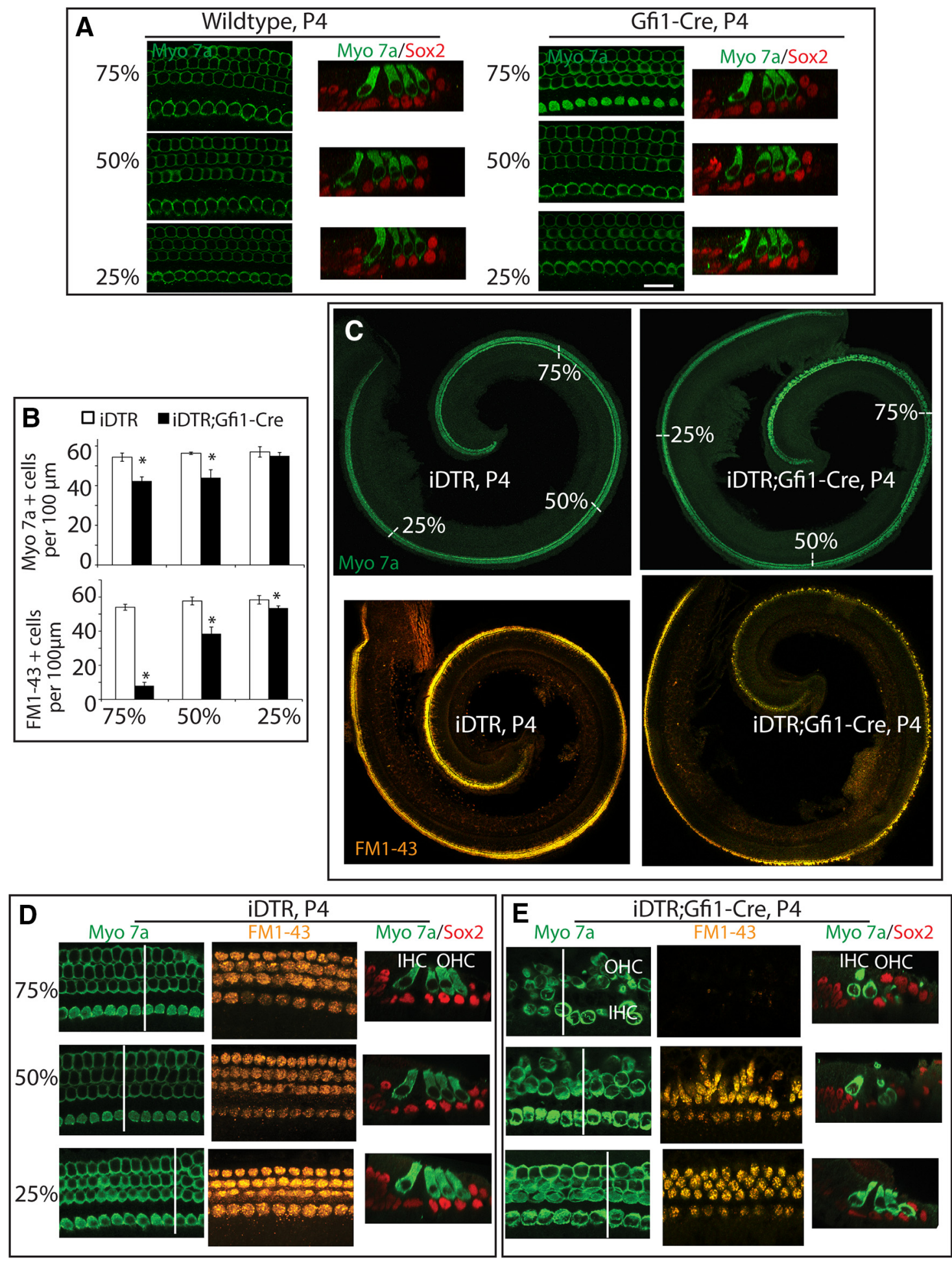

Figure 1. Loss of HCs in different areas of the cochlea (shown as the distance from the hook region of the base to the apex) after DT treatment of transgenic mice. A, HCs were intact in GfiT-Cre mice and their wild-type littermates after DT treatment. B, A decrease in HC number and FM1-43 uptake was seen in the DT-treated DTR ${ }^{\text {flox/+ }}$;Gfi1-Cre (iDTR;Gfi1-Cre) mice. Loss of FM1-43 uptake was more pronounced than outright loss of myosin Vlla-positive cells and was most pronounced in the apical region. The control ear is from a DTR ${ }^{\text {flox/+ }} ;$; GfiT-Cre-negative mouse (iDTR) that received DT. The cochlea was examined at P4. ${ }^{*} p<0.05 . n=4$. Error bars indicate SEM. C, There were no gross structural changes in the organ of Corti from iDTR;GfiT-Cre or control mice following systemic DT administration. $\boldsymbol{D}, \mathrm{HCs}$ in the control ear were positive for myosin VIla and FM1-43; the white line indicates an $x-z$ scan. $\boldsymbol{E}$, iDTR; Gfi1-Cre mice had lost HCs in an apex-to-base gradient; the disorganized rows of HCs did not contain active transduction channels (FM1-43). Supporting cells had moved apically ( $x-z$ scan at the white line) after HC loss. Scale bar, $20 \mu \mathrm{m}$.

Regeneration of HCs after DT-induced cell death

Sensory epithelial cells in the organ of Corti of control (iDTR without Gfil-Cre) mice at P4 did not undergo mitosis (Fig. $2 A, C)$, as shown by the lack of incorporation of EdU, a marker of
DNA replication, and by Ki67, a marker of active phases of the cell cycle. This is consistent with the postmitotic status of auditory HCs and supporting cells in the postnatal sensory epithelium of mammals and the lack of regeneration. Proliferation was only 
seen in the mesenchymal cells beneath the basilar membrane (Fig. 2A). EdU/myosin VIIa double-positive cells, however, were evident at P4 in organ of Corti in iDTR; Gfil-Cre mice receiving DT at P1 (Fig. $2 B)$. Some myosin VIIa-expressing cells in the DT-treated ears also expressed Ki67 (Fig. 2D). Sox2 expression was not detected in postnatal HCs of control (iDTR without Gfi1-Cre) mice at P4 (Fig. 2E), but all ectopic myosin VIIa-positive cells showed strong expression of Sox2 after DT treatment (Fig. 2F), consistent with our previous observation of Sox 2 in new HCs (Bramhall et al., 2014; Kempfle et al., 2016). Sox2-positive HCs were negative for p27Kip1, which was seen in Sox2positive supporting cells (Fig. 2G). A small percentage of myosin VIIa/Sox2 doublepositive cells incorporated EdU, suggesting that new HCs were generated both by mitosis and direct transdifferentiation from supporting cells (Fig. $2 H$ ). When DT was given at later time points, the number of new myosin VIIa/Sox2 double-positive HCs was significantly decreased (Fig. 2I).

\section{Decreased HC regeneration after inhibition of Wnt signaling}

Since Wnt/ $\beta$-catenin signaling is known to lead to supporting cell proliferation and to generate new HCs when induced in the newborn cochlea in vivo (Chai et al., 2012; Shi et al., 2013), we tested for a role of Wnt signaling in the spontaneous regeneration in the iDTR;Gfil-Cre mice. A single dose of IWP-2, an inactivator of porcupine function and inhibitor of Wnt production, directly injected into the DTtreated cochlea in vivo decreased the number of new HCs and proliferation (Fig. $3 A$ ). IWP-2 had no apparent structural effects on the normal or DT-treated ears (Fig. $3 B$ ). No labeling of supporting or HCs with EdU or Sox 2 was seen after treatment of a normal ear with the drug (Fig. 3C), but IWP-2 application to DT-treated ears decreased the number of myosin VIIa/Sox2, as well as myosin VIIa/EdU double-positive cells, compared to the (contralateral) ear without IWP-2 treatment (Fig. $3 D, E$ ).

\section{Increased regeneration of HCs by Notch inhibition after} DT-induced HC death

Notch inhibition and $\mathrm{Wnt} / \beta$-catenin signaling manipulation induced new HCs in postnatal organ of Corti and utricle (Doetzlhofer et al., 2009; Lin et al., 2011; Bramhall et al., 2014). We tested whether inactivation of Notch signaling would further augment the regeneration of HCs seen in the DT-treated ears. Treatment of cultured organ of Corti from iDTR;Gfil-Cre mice with LY411575, a $\gamma$-secretase inhibitor, significantly increased the number of new HCs (Fig. 4A). Based on supporting cell incorporation of BrdU, the differentiation to HCs occurred both by a
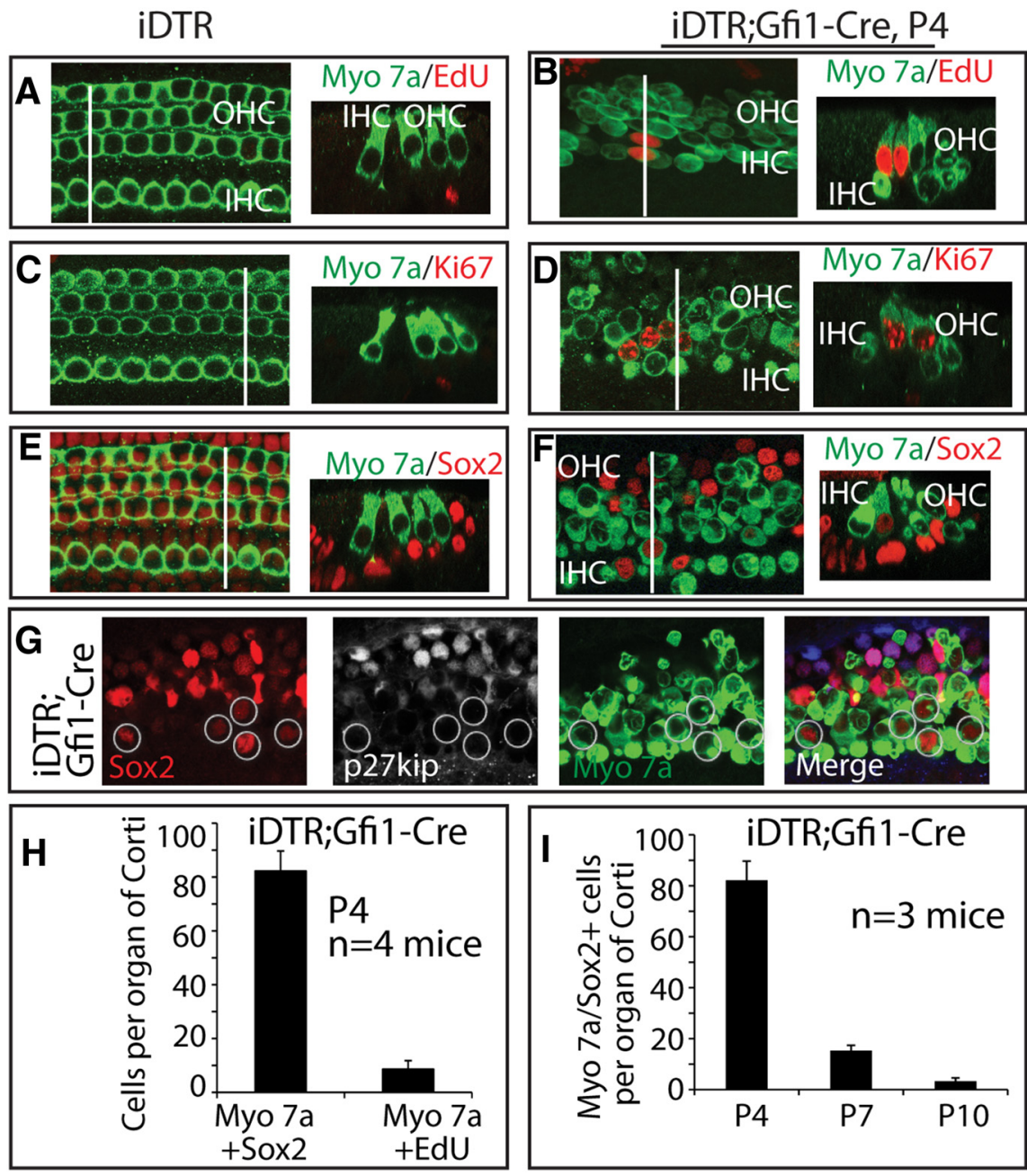

Figure 2. Spontaneous HC regeneration in iDTR;Gfi1-Cre mice. $\boldsymbol{A}$, Lack of EdU incorporation in a control cochlea showed that HCS and supporting cells were postmitotic at P4. HCs were stained with myosin Vlla antibody. The position of an $x-z$ scan is indicated by the white line. $\boldsymbol{B}$, A small number of myosin VIla-positive cells were EdU positive, along with damaged HCs at P4 in iDTR;Gfi1-Cre in the control ear were negative for Ki67, a protein marker for proliferation. An $x-z$ scan was taken at the white line. D, Some

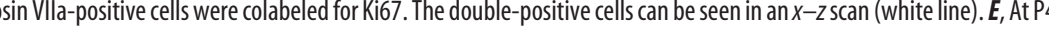
of the myosin VIla cells were positive for Sox 2 in the DT-treated organ of Corti. An $x-z$ scan at the white line shows two myosin VIlla-positive cells in the pillar cell region expressed Sox2. G, Supporting cells were p27Kip positive, and HCs were p27Kip negative. $\boldsymbol{H}$, Quantification of myosin VIla/Sox2-positive cells and myosin VIla/EdU-positive cells in P4 iDTR;Gfi1-Cre mice, in which HC death was induced at P1 with DT. $n=4$ animals per group. $I$, The number of myosin VIla/Sox2-positive cells decreased with age, and few of these cells were visible in P10 organ of Corti. $n=3$ animals at each age. Error bars indicate SEM.

direct mechanism, without supporting cell mitosis, and by supporting cell division followed by $\mathrm{HC}$ differentiation (Fig. $4 B, C$ ). Notch inhibition thus enhanced spontaneous $\mathrm{HC}$ regeneration after DT-induced death of HCs.

\section{No regeneration after neomycin-induced $\mathrm{HC}$ death}

We previously found a low level of spontaneous $\mathrm{HC}$ replacement in cultured gentamycin-treated organ of Corti (Bramhall et al., 2014), but did not examine whether HC replacement occurred in vivo. To gain access to perilymph, we administered aminoglycosides directly into the scala media of the cochlea. The injection site (Fig. $5 A$ ) was $15 \%$ of the distance from the hook region to the apex (equivalent to $55 \mathrm{kHz}$ after hearing onset). Intracochlear application of $200 \mathrm{nl}$ of neomycin at P1 resulted in dosedependent (up to $90 \%$ at $50 \mathrm{~mm}$ ) $\mathrm{OHC}$ and IHC loss at $\mathrm{P} 4$, with increasing IHC damage at high concentrations (Fig. $5 A, B$ ). In 


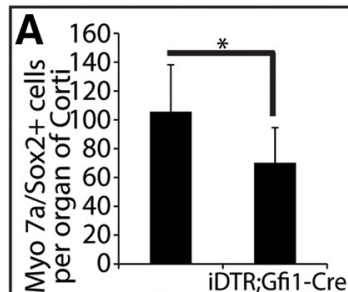
iDTR;Gfi1-Cre +IWP-2
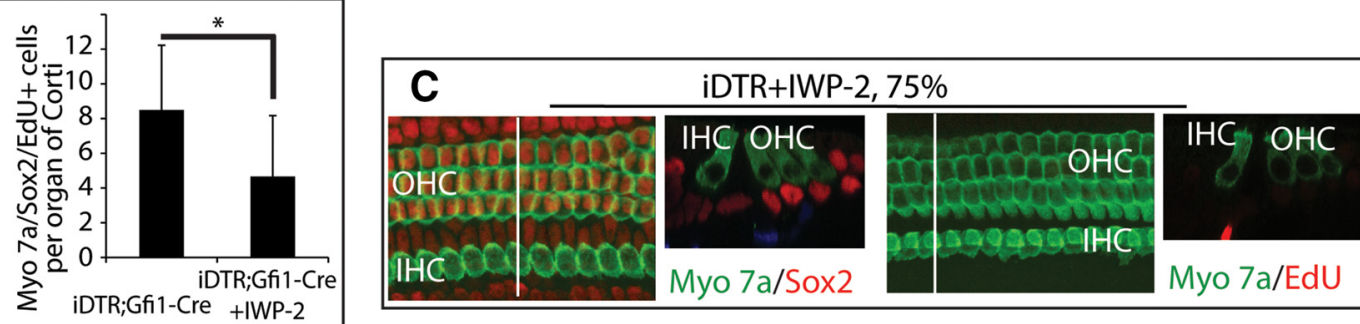
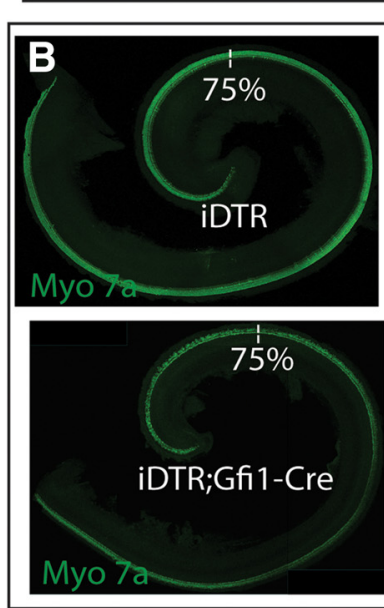
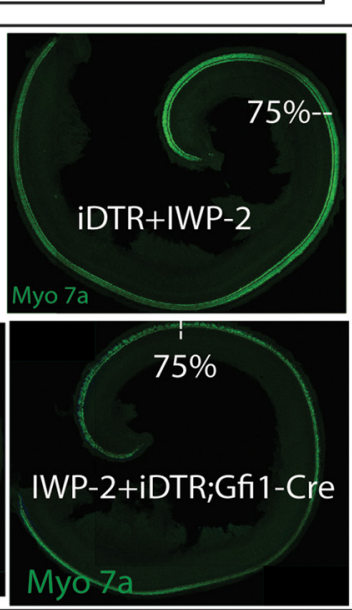
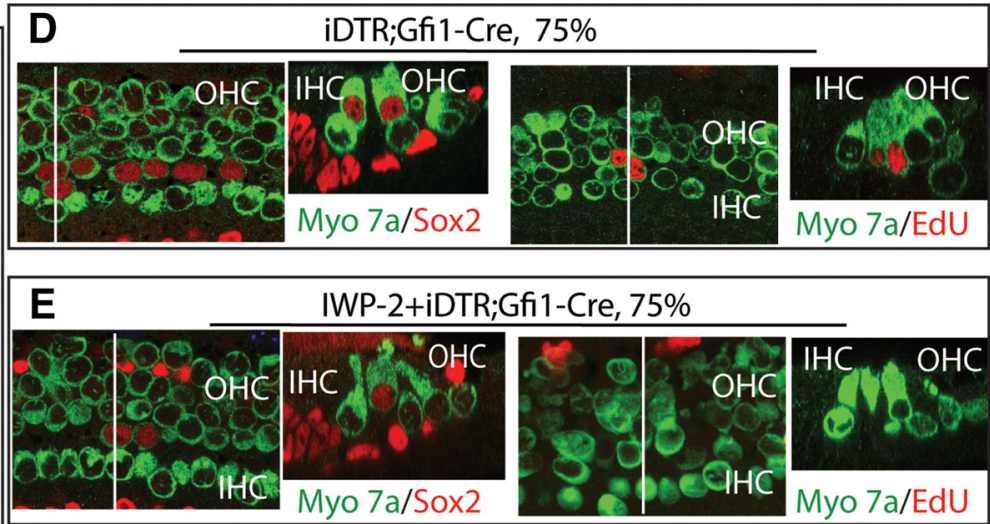

Figure 3. Wnt inhibition decreased spontaneous HC regeneration. $A$, IWP-2, a Wnt inhibitor, applied directly to the cochlea, significantly decreased the number of myosin VIla/Sox2 doublepositive cells and the number of myosin VIla/EdU double-positive cells in the organs of Corti upon DT treatment. Error bars indicate SEM. ${ }^{*} p<0.05 . n=4$. $B$, IWP-2 applied to the normal ear had no effect on gross organ of Corti morphology in the control or iDTR; GfiT-Cre cochleas. C, IWP-2 had no effect on HCs or supporting cells in the control mouse, which was negative for EdU. An $x-z$ scan, shown in $E$, was taken at the white line. $D$, In the organ of Corti of iDTR;GfiT-Cre mice after DT treatment, some myosin VIla-positive cells were also positive for Sox2 and incorporated EdU. In an $x-Z$ scan at the white line, myosin VIla-positive cells that expressed Sox2 and incorporated EdU were in the pillar cell region. E, IWP-2-treated iDTR;GfiT-Cre ears had fewer myosin VIla/Sox2 and myosin $\mathrm{VIla} / \mathrm{EdU}$ double-positive cells. $x-z$ scans were taken at the white lines.
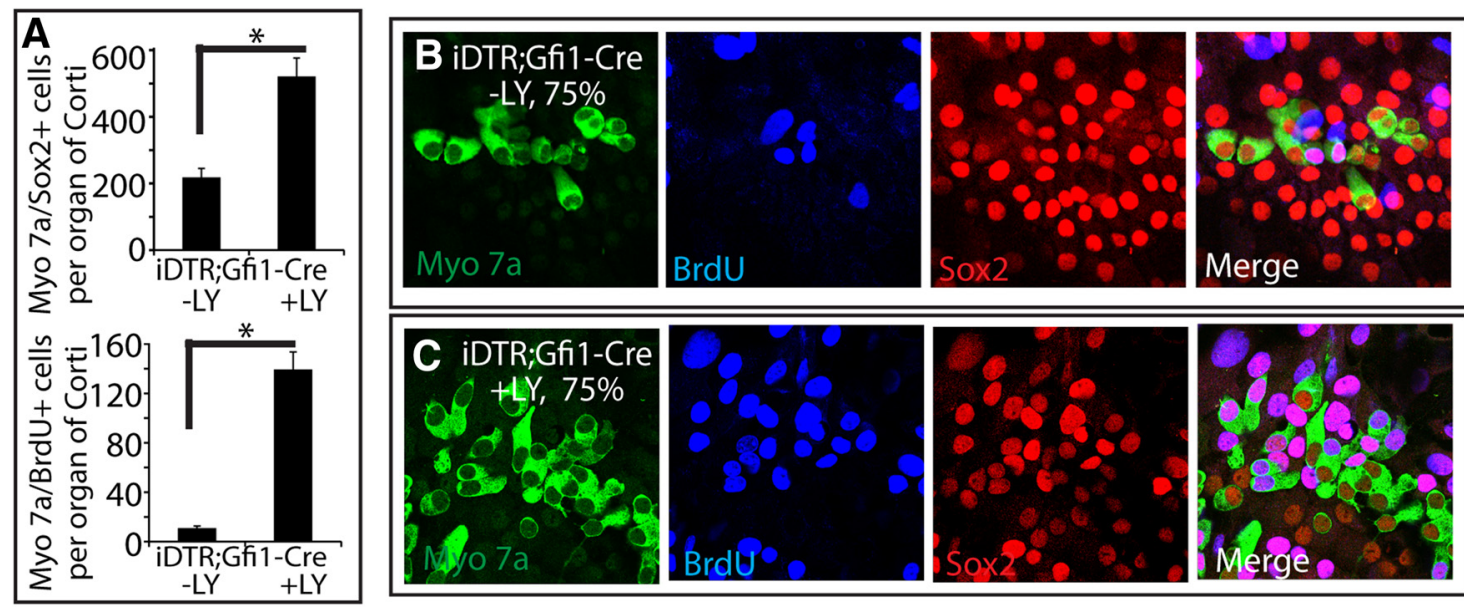

Figure 4. Notch inhibition increased the number of HCs in the DT-treated organ of Corti. A, Treatment of cultured organ of Corti from an iDTR;Gfi7-Cre mouse with $\gamma$-secretase inhibitor, LY411575 (LY), increased the number of new HCs compared to an iDTR;GfiT-Cre organ of Corti without LY treatment. Error bars indicate SEM. ${ }^{*} p<0.05 . n=3$. B, An iDTR; GfiT-Cre mouse had myosin VIlla/Sox2 double-positive cells, some of which were BrdU positive. C, An organ of Corti isolated from an iDTR;GfiT-Cre mouse and treated with LY411575 gave rise to an increased number of myosin VIla/Sox2 and myosin VIla/BrdU double-positive cells.

contrast to the effects of DTR, no myosin VIIa/Sox2 doublepositive cells or EdU incorporation were seen after neomycin treatment (Fig. 5C,D).

Changes in gene expression in DT vs neomycin-treated inner ear

Since previous studies have shown involvement of both Notch and Wnt $\beta$-catenin signaling in HC generation in the newborn ear (Shi et al., 2013), we assessed activation of Wnt and Notch pathways in the DT- and neomycin-treated organ of Corti. No change was seen in Wnts or Wnt pathway molecules $1 \mathrm{~d}$ after DT or neomycin injection (Fig. 6A,B), whereas increased expression of Wnt1, Wnt2, Wnt2b, Wnt4, Wnt5a, Wnt7b, Wnt9a, Wnt9b, and Wnt11, as well as Dickkopf (Dkk) receptor Krm2, were apparent $3 \mathrm{~d}$ after DT treatment in the iDTR;Gfil-Cre cochlea, and other Wnt molecules remained either unchanged or undetectable (Fig. 6C). In the neomycin-treated ears, however, all Wnt molecules remained unchanged or undetectable, except Wnt16 and Wnt11 (Fig. 6D). 
We further analyzed the neomycininduced HC death. Annexin V has a high affinity to phosphatidylserine, which is normally hidden within the cell membrane but appears in the outer leaflet of the cell membrane during apoptosis. Annexin $\mathrm{V}$-positive HCs were observed 30 min after neomycin injection (Fig. 7A), but not in the control or DT-treated ears. Cleaved caspase-3-positive cells were also seen in the neomycin-injected ears (Fig. $7 C)$, and the number of cleaved caspase3-positive HCs was significantly increased in the neomycin-injected cochlea (Fig. $7 F$ ). HCs in iDTR; Gfil-Cre mice showed increased permeability to propidium iodide (Fig. 7B). In agreement with differential expression of Wnt ligands, active $\beta$-catenin was seen in HCs and supporting cells in the iDTR; Gfil-Cre ear following DT injection, whereas the control and neomycin injected ears did not accumulate active $\beta$-catenin (Fig. 7D). Cells that had undergone division in the iDTR; GfilCre ear also contained active $\beta$-catenin (Fig. $7 E$ ), while there was a lack of such cells in the neomycin-injected cochlea (Fig. $7 F$ ).

Regeneration of HCs by forced activation of $\boldsymbol{\beta}$-catenin after neomycin-induced $\mathrm{HC}$ death

We next examined whether forced activation of Wnt/ $\beta$-catenin signaling could induce new $\mathrm{HC}$ generation following neomycin-induced HC loss. We used Sox2-Cre-ER mice to activate $\beta$-catenin constitutively in all supporting cells by crossing to a $\beta$-catenin flox(exon 3$)$ mouse, in which conditional deletion of exon3 $\left(\beta\right.$-catenin $\left.{ }^{\Delta \text { exon } 3}\right)$ blocks $\beta$-catenin degradation and induces accumulation of $\beta$-catenin. We administered neomycin to one ear to induce $\mathrm{HC}$ death at P1 and tamoxifen systemically to activate $\beta$-catenin in both ears at P2. At P5, $\beta$-catenin overexpression induced myosin VIIa-positive cells $30 \%$ from the base, where there was a complete absence of myosin VIIa cells in control ears (Fig. $8 A, B$ ). No EdU-positive cells were observed in the $\beta$-catenin-activated cochlea without HC damage by neomycin (Fig. $8 C$ ).

Myosin VIIa/EdU double-positive cells in the neomycin-treated ear after $\beta$-catenin overexpression were seen at the apex in the pillar cell region, along with remaining HCs (Fig. 8D), consistent with our previous finding (Shi et al., 2013). The EdU incorporation is likely in supporting cells, since $\beta$-catenin upregulation drives supporting cell proliferation and transdifferentiation in the newborn cochlea (Shi et al., 2013), but does not affect hair cells (Shi et al., 2013). The number of new HCs in the neomycin treated, $\beta$-catenin-stabilized ears was higher than in ears where $\beta$-catenin was upregulated in the absence of damage induced by neomycin (Fig. $8 E$ ). Lethality of $\beta$-catenin overexpression precluded examination at a later age. Thus, forced
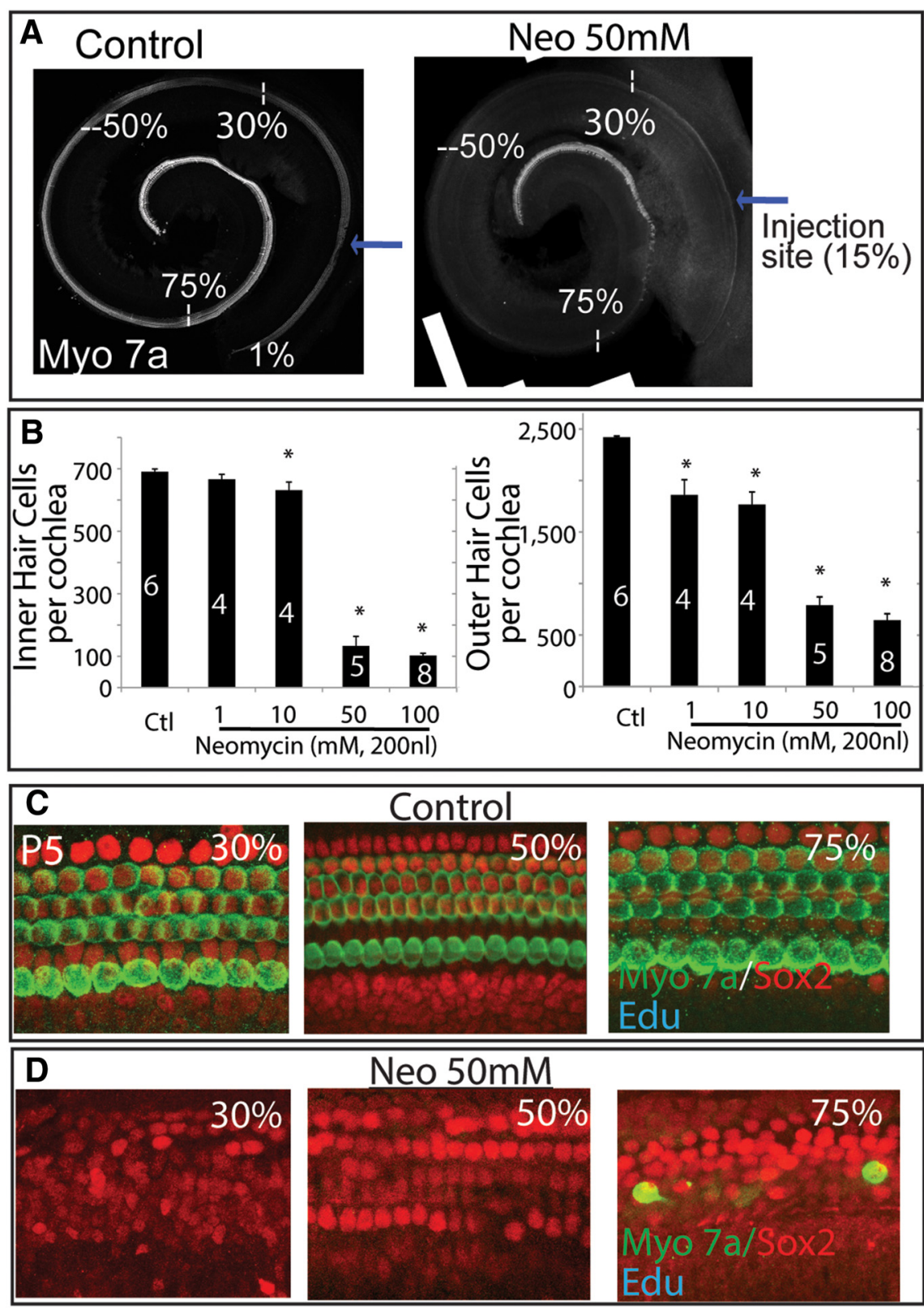

Figure 5. Lack of $\mathrm{HC}$ regeneration in the neomycin treated cochlea. $A$, A single dose $(200 \mathrm{nl})$ of $50 \mathrm{~mm}$ neomycin into the $\mathrm{P2}$ cochlea resulted in a complete loss of $\mathrm{HCs}$ from the injection site which was $15 \%$ from the base (indicated by the arrows). No HC loss was seen in control cochlea with carrier injection between the injection site and the midapex (75\% from the base). HCs were stained with myosin VIla. $\boldsymbol{B}$, A dose-dependent $\mathrm{HC}$ loss was observed with intracochlear injection of neomycin. More IHC than $\mathrm{OHC}$ bars indicate SEM. ${ }^{*} p<0.05$. C, The contralateral ear without neomycin had an overall normal structure, with myosin VIla-positive HCS, Sox2-positive supporting cells, and no EdU incorporation. D, A complete lack of myosin VIlla-positive cells in the 30 and $50 \%$ regions and a nearly complete loss at the $75 \%$ region were seen in the neomycin-treated ear. No EdU-positive cells were observed.

activation of $\beta$-catenin regenerated HCs in neomycin-treated organ of Corti, and more HCs were generated in the neomycin-treated than in the intact organ of Corti.

\section{Discussion}

We show here that significant regeneration of HCs can occur in the newborn mouse cochlea depending on the mechanism of cell death. We find that supporting cells reenter the cell cycle after in vivo $\mathrm{HC}$ death induced by DT but not neomycin in the newborn cochlea. Mechanisms of cell death induced by ligation of the DTR or by aminoglycosides, after their entry into HCs through trans- 

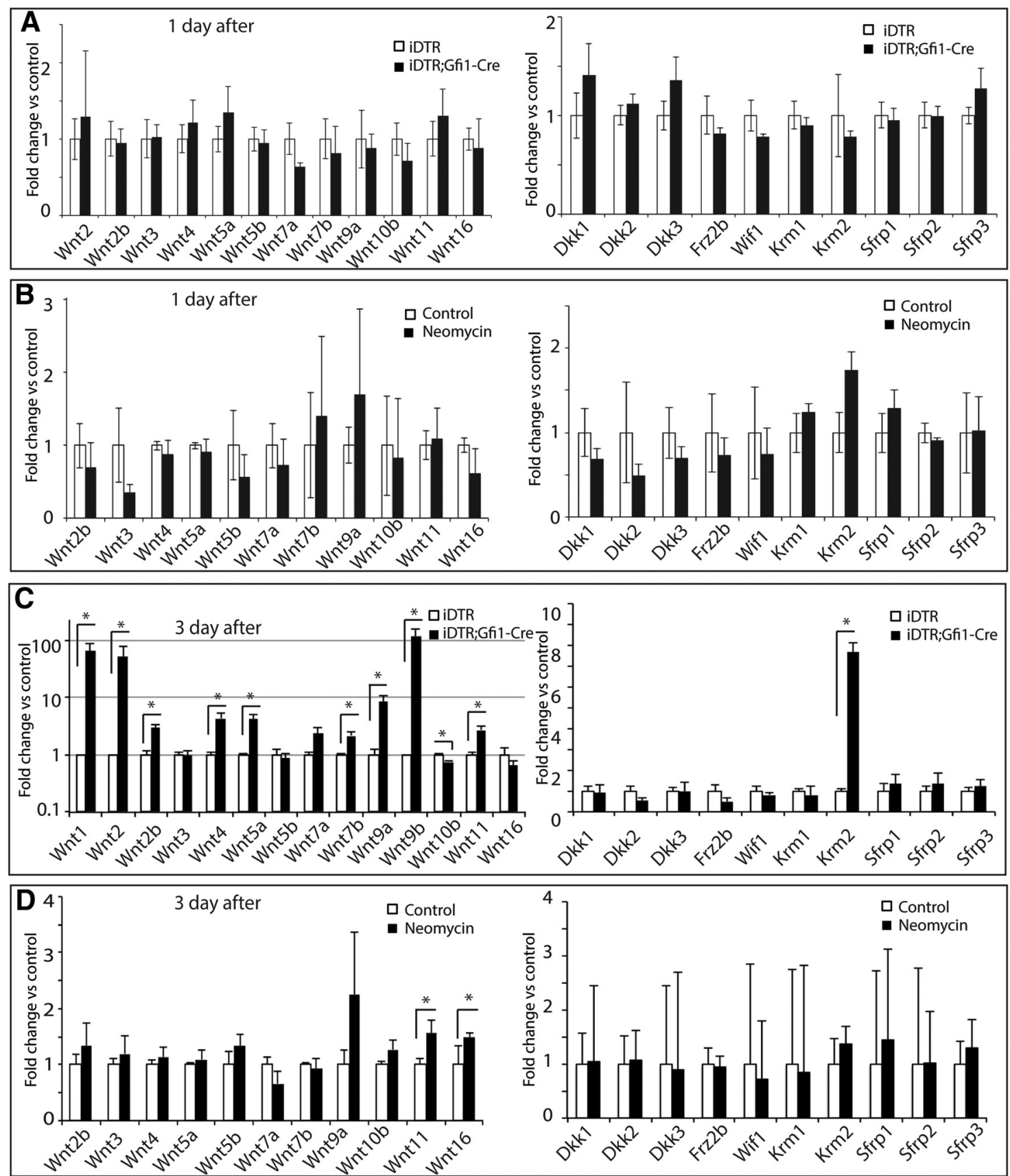

Figure 6. Wnt expression is upregulated in ears with spontaneous $\mathrm{HC}$ regeneration. $\boldsymbol{A}$, Expression of Wnts and Wnt antagonists by quantitative PCR showed no changes $1 \mathrm{~d}$ after treatment with DT in iDTR;Gfi1-Cre mice. $\boldsymbol{B}$, No changes in expression of Wnts and Wnt antagonists were observed $1 \mathrm{~d}$ after treatment neomycin-induced HC loss. $\boldsymbol{C}$, Expression of several Wnts showed significant increases $3 \mathrm{~d}$ after DT treatment in iDTR;Gfi1-Cre mice. Krm2 also increased in iDTR;Gfi1-Cre mice. D, Wnt16 and Wnt11 showed small but significant increases $3 \mathrm{~d}$ after neomycin treatment. 0ther Wnt-related molecules showed no change or were undetectable after neomycin treatment. Error bars indicate SEM. ${ }^{*} p<0.05 . n=4$.

duction channels, are distinct. DT binds its receptor, eventually leading to cell membrane rupture and release of cellular components (Collier and Kandel, 1971), whereas gentamicin disturbs mitochondrial function and activates apoptosis cascades (Matsui et al., 2003; Momiyama et al., 2006; Huth et al., 2011) without disrupting the cell membrane (Warchol, 2010). HC loss after neomycin treatment in our experiments occurred within a day, and membrane lipid changes were seen by $30 \mathrm{~min}$. In contrast, DT treatment decreased cell membrane integrity and permeability to propidium iodide, resulting in damage to the bundle (reflected in a loss of mechanotransduction channel function); HC loss was slower and was not preceded by reorganization of mem- brane lipids. Although cell death after neomycin or DTR was not exclusively apoptotic or necrotic, neomycin, here as in previous studies (Forge and Li, 2000; Warchol, 2010), induced a largely apoptotic mechanism of cell death, whereas DT induced a mixture of apoptotic and necrotic mechanisms.

Wnts were upregulated and $\beta$-catenin became transcriptionally active after DT-induced damage, but not after neomycin treatment. Inhibition of regeneration by a Wnt inhibitor suggested a correlation of regeneration with $\mathrm{Wnt} / \beta$-catenin signaling after DT treatment. A number of Wnts (Wnt1, Wnt2, Wnt2b, Wnt4, Wnt5a, Wnt7b, Wnt9a, Wnt9b, Wnt11) were upregulated after DT-induced cell death. In conjunction with the upregula- 
tion of Wnts, an increase in an active form of $\beta$-catenin in HCs and supporting cells was consistent with a mechanism involving autocrine and paracrine Wnt signaling. Upregulation of $\mathrm{Krm} 2$, a receptor for Wnt inhibitor, Dickkopf, may have been part of a negative feedback loop that would decrease Wnt activity, although $\mathrm{Krm} 2$ can also act as an activator of Wnt signaling (Hassler et al., 2007) and could thus increase the response. In the neonatal mouse utricle, ex vivo ablation of $\mathrm{HCs}$ with neomycin activated the Wnt target gene, $\operatorname{Lgr} 5$, in the striolar region and led to $\mathrm{HC}$ regeneration through mitotic and direct differentiation mechanisms (Wang et al., 2015). Upregulation of these genes is consistent with a recent comprehensive study of the expression of Wnt pathway genes in the cochlea (Geng et al., 2016). Many Wnt ligands, Frizzled receptors, and Wnt antagonists, such as Dkk3, Sfrp1, and Sfrp3, were dynamically expressed both prenatally and postnatally. The level of $\beta$-catenin in cells of the sensory epithelium could thus be a result of activity of both Wnts and Wnt antagonists acting in complimentary locations.

Apoptotic cells are extruded by the concerted contraction of their neighbors and formation of a ring of actin and myosin in surrounding cells (Rosenblatt et al., 2001). The supporting cells that surround HCs send out extensions and close off the epithelial surface as a part of the damage response (Meiteles and Raphael, 1994; Anttonen et al., 2012). Actin filaments grow into the space left after loss of the stereociliary bundles of the HCs, resulting in an area that is intact, but without HCs. Actin rings at the surface of the epithelium have been postulated to play a role in preventing regeneration in the mouse (Collado et al., 2011). Cadherins inhibited by Wnt signaling can also act as repressors of cell division (Shi et al., 2014). The integrity of the membrane in cells undergoing apoptosis reduces the inflammatory response, and strand breaks in DNA between nucleosomes in apoptotic cell death are less disruptive to the cell than the random cleavage of necrosis (Günther et al., 2013; Galluzzi et al., 2014). Apoptosis in-

duces less inflammation but can release TNF, leading to recruitment of inflammatory cytokines, and, indeed, developmental apoptosis in the nervous system is a requisite step in the subsequent differentiation of neurons (Hyman and Yuan, 2012) and a general developmental mechanism for tissue morphogenesis (Hernández-Martínez and Covarrubias, 2011; Suzanne and Steller, 2013).

Wnts are released by many other tissues in response to damage and, along with inflammatory cytokines and FGFs, form one arm of the damage response (Hassler et al., 2007; Whyte et al., 2012).
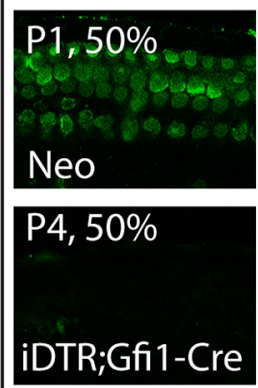
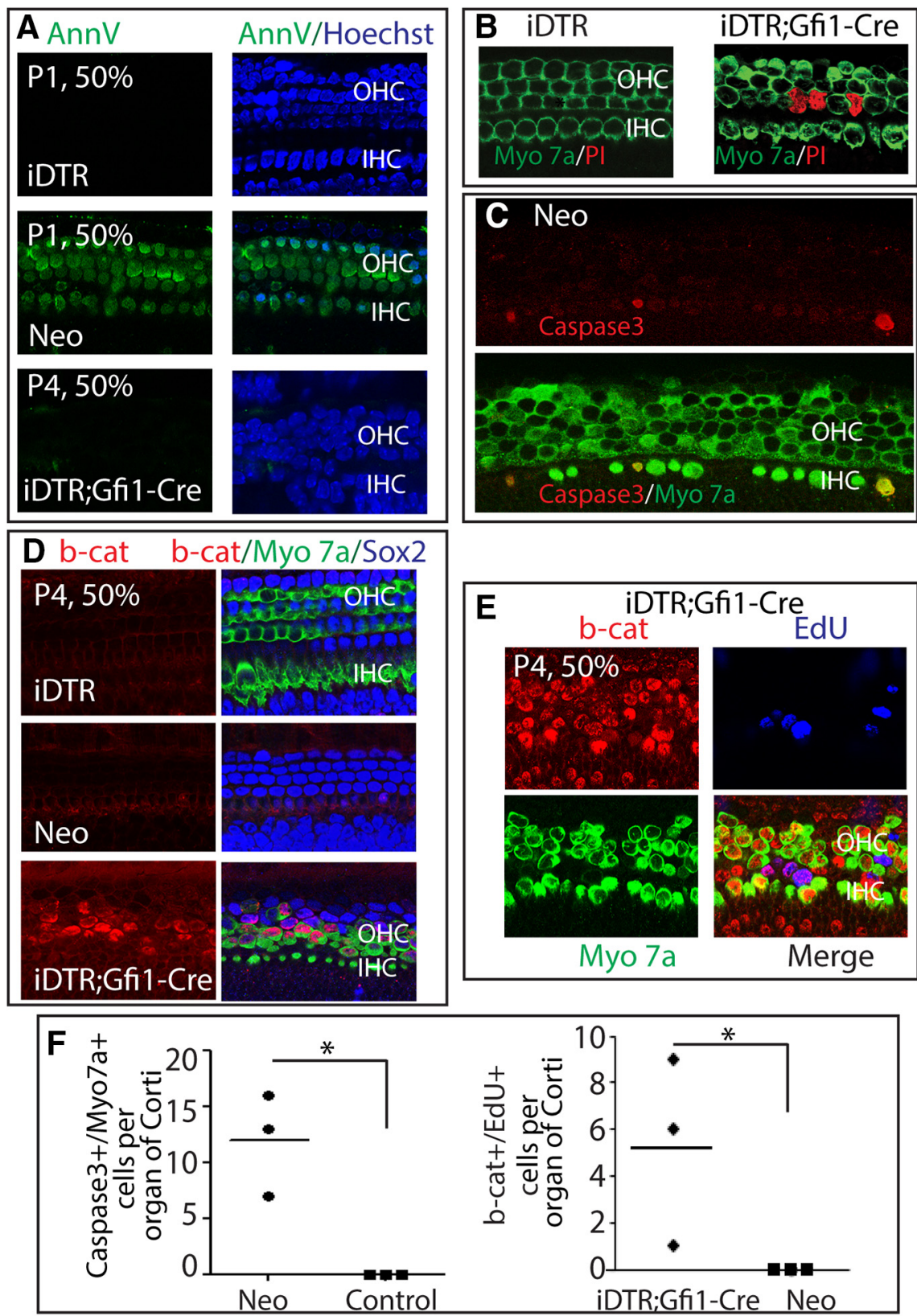

Figure 7. DT-induced HC loss leads to activation of the Wnt pathway. $A$, Annexin V (AnnV)-positive HCs were observed 30 min after neomycin injection ( $\mathrm{Neo}$ ) into the cochlea at P1. Annexin V-positive cells were not present in the contralateral ear (Control) or in the DT-injected iDTR;GfiT-Cre ear. Hoechst was used to stain the nuclei and locate HCs in the live tissue. B, HCs in iDTR;GfiT-Cre mice, but not control mice, stained with propidium iodide (PI), while supporting cells in control and iDTR ears remained PI negative. C, Cleaved caspase-positive cells were seen in the neomycin-injected ear. $\boldsymbol{D}$, Transcriptionally active Y498 $\beta$-catenin (b-cat) was observed in HCs and supporting cells of a DT-injected iDTR;GfiT-Cre ear, whereas control and neomycin-injected ears did not show accumulation of active $\beta$-catenin. $\boldsymbol{E}$, Active $\beta$-catenin was observed in EdU-positive cells in the iDTR;GfiT-Cre ear. $\boldsymbol{F}$, Caspase-3/ myosin VIla double-positive cells were significantly increased after neomycin treatment. $\beta$-catenin/EdU double-positive cells were only observed in iDTR;GfiT-Cre mice after DT treatment. $n=3$ animals in each group. Error bars indicate SEM. ${ }^{*} p<0.05$.

Wnt signaling is important for the repair of damage in muscle, intestine, and hair follicles in mammals (Ireland et al., 2004; Silva-Vargas et al., 2005; Snyder et al., 2013) and is critical for blastema formation to initiate limb regeneration in amphibians (Kawakami et al., 2006; Yokoyama et al., 2007; Sun and Irvine, 2014). Signaling leading to apoptotic cell death is crucial to the formation of blastemas and regrowth of amphibian limbs. Cell division in the developing blastema occurs in response to cell death. An essential role for Wnt signaling has been established in regeneration in amphibians and lower vertebrates, although the 
A $\mathrm{NeO}$

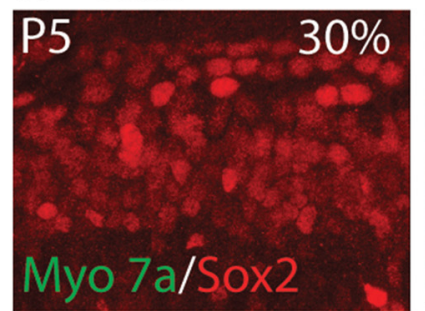

\section{c $\beta$-catenin}

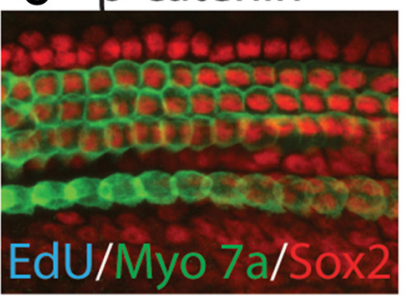

E

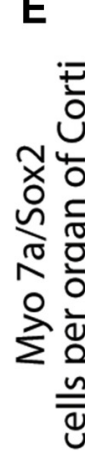

B Neo+ $\beta$-catenin

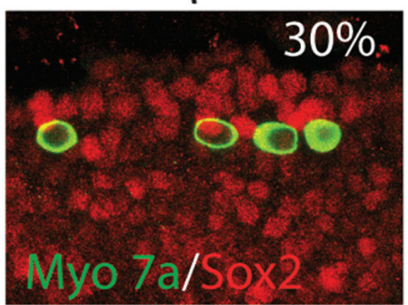

D Neo+ $\beta$-catenin

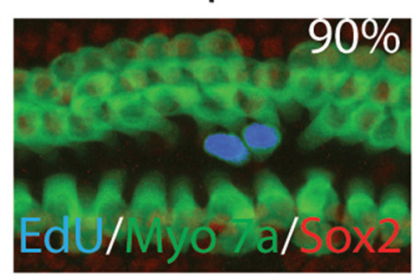

*

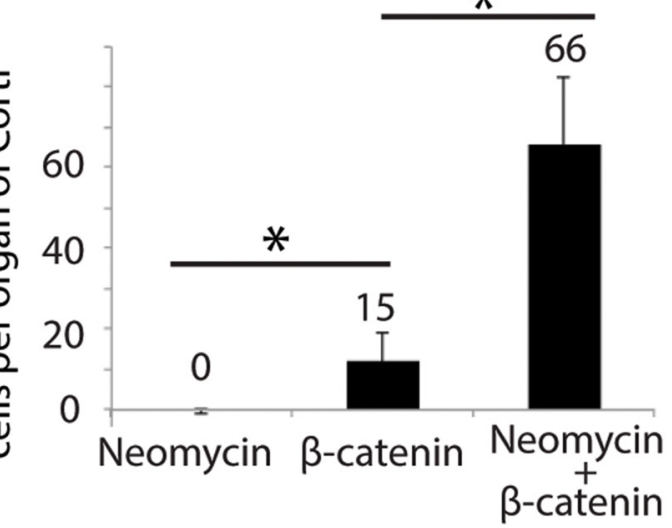

Figure 8. Wnt $/ \beta$-catenin induced $\mathrm{HC}$ regeneration in the neomycin-treated ear. $A, A$ complete loss of HCs was seen in the basal half of the neomycin-treated cochlea. HCs were stained with myosin VIla and supporting cells with Sox2. $\boldsymbol{B}$, Constitutive activation of $\beta$-catenin in a neomycin-treated ear had myosin VIla-positive $\mathrm{HCs}$ in the region $30 \%$ from the base. $\boldsymbol{C}$, No $\mathrm{EdU} /$ myosin VIla double-positive cells were observed in $\beta$-catenin activated cochlea without $\mathrm{HC}$ damage by neomycin. $\boldsymbol{D}$, In the apical region, $\beta$-catenin activation induced ectopic myosin $\mathrm{V}$ Ila/EdU-positive cells. $\boldsymbol{E}$, No new HCs were generated in the ears receiving only neomycin. $\beta$-catenin activation generated more new HCs in neomycin-injected than intact ears. $n=4$ animals in each group. ${ }^{*} p<0.05$.

exact signal that stimulates the release of Wnts has not been completely characterized. Wnt also organizes the stem cell niche in mammals: Wnt3a released from Paneth cells acts on the adjacent stem cells, constituting a stem cell niche at the base of the crypts in the mammalian gut in which one cell relays a signal to the next (Sato et al., 2011).

The correlation of Wnt activation and regeneration in our studies sheds new light on the role for Wnt, although, as in the studies on limb and fin regeneration, the precise role of cell death in the activation of Wnt signaling remains to be determined. The difference seen between DT- and neomycin-induced HC death was presumably due to the upregulation of Wnt signaling in the DT-treated ear. We cannot exclude the possibility that neomycin upregulates Wnt at later time points than we studied. In the organ of Corti, the Wnt dependence of proliferation was not unexpected, as Wnt upregulation via stabilized $\beta$-catenin also leads to proliferation of organ of Corti cells in vivo (Chai et al., 2012; Shi et al., 2012, 2013; Kuo et al., 2015). Our previous work also demonstrated that $\mathrm{Wnt} / \beta$-catenin regulates expression of Atoh1, a key
HC gene, leading to $\mathrm{HC}$ generation in postnatal organ of Corti (Shi et al., 2010).

In vitro experiments showed detectable regeneration without intervention after treatment of the cochlea dissected from newborn mice with gentamycin (Bramhall et al., 2014). However, supporting cells did not incorporate BrdU and were only generated in significant numbers after inhibition of Notch. A regenerative response to aminoglycoside-induced $\mathrm{HC}$ loss in vitro could correspond to a higher percentage of necrotic cell death due to the removal of the cochlea from the animal into an artificial and potentially oxidative environment. The lack of a regenerative response to neomycin in vivo could be due to the low Wnt secretion falling below a threshold required for proliferation. Notch inhibition increased proliferation after DT-induced death of HCs, which we believe is due to removing inhibitory effects of Notch on Wnt signaling. Upregulation of Wnt activity can increase Notch signaling and may prevent overexuberant HC proliferation and differentiation, acting as a brake on the regenerating cells. Notch signaling is under the control of Wnt signaling in somitogenesis, through its influence on Dll1 (Galceran et al., 2004; Chesebro et al., 2013; Bone et al., 2014). In an in vitro organ of Corti, Notch signaling was maintained in supporting cells, and, indeed, the supporting cells transdifferentiated into HCs when Notch signaling was blocked by inhibition of $\gamma$-secretase (Korrapati et al., 2013). In our in vivo experiments on Notch inhibition (Mizutari et al., 2013), we found that Notch signaling was upregulated by exposure to a level of noise sufficient to kill HCs and that inhibition of Notch signaling with a $\gamma$-secretase inhibitor resulted in differentiation of new HCs from supporting cells even in the adult. Notch inhibition was only effective in increasing the yield of new HCs after damage in other studies when Wnt was active (Bramhall et al., 2014). In the experiments described here, inhibition of Wnt blocked regeneration resulting from damage.

The spontaneous regeneration of HCs in the cochlea of chicks after damage is preceded by upregulation of Wnt signals (Ku et al., 2014), and Wnt signaling increases supporting cell proliferation in newly formed lateral line neuromasts (Ma et al., 2008; Head et al., 2013). Moreover, secretion of Dkk by HCs in the zebrafish, by blocking the effect of Wnt on supporting cell proliferation, imposes a limit on the number of HCs produced, and, thus, Wnt plays an important role in the regeneration of sensory epithelia in lower vertebrates (Wada et al., 2013). Despite the evolutionary loss of regenerative capacity in mammals, some of the same pathways are involved, and chick and fish inner ears may not have fundamentally different responses from the mammal.

Supporting cells and HCs in the organ of Corti exit the cell cycle several days before birth in the mouse and are not replaced after damage in the adult. Although our study did not present direct evidence on supporting cell conversion to HCs, spontaneous conversion of supporting cells to HCs has been demonstrated previously in mouse after damage to the postnatal organ of Corti (Bramhall et al., 2014; Cox et al., 2014). The question of whether potential stem cells in the cochlea are activated by cell death is important because of the role of stem cells in the repair of damage. The regenerative response differed after DT- and neomycininduced cell death. The regeneration of HCs in the newborn and its correlation with a difference in activation of the Wnt pathway suggests that the ability to regenerate is retained in mammals, and the loss of regenerative capacity as mammals mature may reflect a higher threshold and not an absolute block. A similar threshold must be overcome during limb regeneration in amphibians, 
where the ability to regenerate also becomes less pronounced at adult ages and can be restored by Wnt augmentation (Kawakami et al., 2006). Understanding the triggers that initiate regeneration in the newborn mouse model will enable future approaches to regeneration in the cochlea.

\section{References}

Anttonen T, Kirjavainen A, Belevich I, Laos M, Richardson WD, Jokitalo E, Brakebusch C, Pirvola U (2012) Cdc42-dependent structural development of auditory supporting cells is required for wound healing at adulthood. Sci Rep 2:978. Medline

Arnold K, Sarkar A, Yram MA, Polo JM, Bronson R, Sengupta S, Seandel M, Geijsen N, Hochedlinger K (2011) Sox2(+) adult stem and progenitor cells are important for tissue regeneration and survival of mice. Cell Stem Cell 9:317-329. CrossRef Medline

Bermingham-McDonogh O, Rubel EW (2003) Hair cell regeneration: winging our way towards a sound future. Curr Opin Neurobiol 13: 119-126. CrossRef Medline

Bone RA, Bailey CS, Wiedermann G, Ferjentsik Z, Appleton PL, Murray PJ, Maroto M, Dale JK (2014) Spatiotemporal oscillations of Notch1, Dll1 and NICD are coordinated across the mouse PSM. Development 141: 4806-4816. CrossRef Medline

Bramhall NF, Shi F, Arnold K, Hochedlinger K, Edge AS (2014) Lgr5positive supporting cells generate new hair cells in the postnatal cochlea. Stem Cell Rep 2:311-322. CrossRef

Buch T, Heppner FL, Tertilt C, Heinen TJ, Kremer M, Wunderlich FT, Jung S, Waisman A (2005) A Cre-inducible diphtheria toxin receptor mediates cell lineage ablation after toxin administration. Nat Methods 2:419-426. CrossRef Medline

Cafaro J, Lee GS, Stone JS (2007) Atoh1 expression defines activated progenitors and differentiating hair cells during avian hair cell regeneration. Dev Dyn 236:156-170. CrossRef Medline

Chai R, Kuo B, Wang T, Liaw EJ, Xia A, Jan TA, Liu Z, Taketo MM, Oghalai JS, Nusse R, Zuo J, Cheng AG (2012) Wnt signaling induces proliferation of sensory precursors in the postnatal mouse cochlea. Proc Natl Acad Sci U S A 109:8167-8172. CrossRef Medline

Chesebro JE, Pueyo JI, Couso JP (2013) Interplaybetween aWnt-dependent organiser and the Notch segmentation clock regulates posterior development in Periplaneta americana. Biol Open 2:227-237. CrossRef Medline

Collado MS, Thiede BR, Baker W, Askew C, Igbani LM, Corwin JT (2011) The postnatal accumulation of junctional E-cadherin is inversely correlated with the capacity for supporting cells to convert directly into sensory hair cells in mammalian balance organs. J Neurosci 31:11855-11866. CrossRef Medline

Collier RJ, Kandel J (1971) Structure and activity of diphtheria toxin. I. Thiol-dependent dissociation of a fraction of toxin into enzymically active and inactive fragments. J Biol Chem 246:1496-1503. Medline

Cox BC, Chai R, Lenoir A, Liu Z, Zhang L, Nguyen DH, Chalasani K, Steigelman KA, Fang J, Rubel EW, Cheng AG, Zuo J (2014) Spontaneous hair cell regeneration in the neonatal mouse cochlea in vivo. Development 141:816-829. CrossRef Medline

Daudet N, Gibson R, Shang J, Bernard A, Lewis J, Stone J (2009) Notch regulation of progenitor cell behavior in quiescent and regenerating auditory epithelium of mature birds. Dev Biol 326:86-100. CrossRef Medline

Doetzlhofer A, Basch ML, Ohyama T, Gessler M, Groves AK, Segil N (2009) Hey2 regulation by FGF provides a Notch-independent mechanism for maintaining pillar cell fate in the organ of Corti. Dev Cell 16:58-69. CrossRef Medline

Forge A, Li L (2000) Apoptotic death of hair cells in mammalian vestibular sensory epithelia. Hear Res 139:97-115. CrossRef Medline

Galceran J, Sustmann C, Hsu SC, Folberth S, Grosschedl R (2004) LEF1mediated regulation of Delta-like1 links Wnt and Notch signaling in somitogenesis. Genes Dev 18:2718-2723. CrossRef Medline

Galluzzi L, Kepp O, Krautwald S, Kroemer G, Linkermann A (2014) Molecular mechanisms of regulated necrosis. Semin Cell Dev Biol 35:24-32. CrossRef Medline

Geng R, Noda T, Mulvaney JF, Lin VY, Edge AS, Dabdoub A (2016) Comprehensive expression of Wnt signaling pathway genes during development and maturation of the mouse cochlea. PLoS One 11:e0148339. CrossRef Medline

Günther C, Neumann H, Neurath MF, Becker C (2013) Apoptosis, necrosis and necroptosis: cell death regulation in the intestinal epithelium. Gut 62:1062-1071. CrossRef Medline

Harada N, Tamai Y, Ishikawa T, Sauer B, Takaku K, Oshima M, Taketo MM (1999) Intestinal polyposis in mice with a dominant stable mutation of the beta-catenin gene. EMBO J 18:5931-5942. CrossRef Medline

Hassler C, Cruciat CM, Huang YL, Kuriyama S, Mayor R, Niehrs C (2007) Kremen is required for neural crest induction in Xenopus and promotes LRP6-mediated Wnt signaling. Development 134:4255-4263. CrossRef Medline

Head JR, Gacioch L, Pennisi M, Meyers JR (2013) Activation of canonical Wnt/beta-catenin signaling stimulates proliferation in neuromasts in the zebrafish posterior lateral line. Dev Dyn 242:832-846. CrossRef Medline

Hernández-Martínez R, Covarrubias L (2011) Interdigital cell death function and regulation: new insights on an old programmed cell death model. Dev Growth Differ 53:245-258. CrossRef Medline

Huth ME, Ricci AJ, Cheng AG (2011) Mechanisms of aminoglycoside ototoxicity and targets of hair cell protection. Int J Otolaryngol 2011:937861. Medline

Hyman BT, Yuan J (2012) Apoptotic and non-apoptotic roles of caspases in neuronal physiology and pathophysiology. Nat Rev Neurosci 13: 395-406. Medline

Ireland H, Kemp R, Houghton C, Howard L, Clarke AR, Sansom OJ, Winton DJ (2004) Inducible Cre-mediated control of gene expression in the murine gastrointestinal tract: effect of loss of beta-catenin. Gastroenterology 126:1236-1246. CrossRef Medline

Kawakami Y, Rodriguez Esteban C, Raya M, Kawakami H, Martí M, Dubova I, Izpisúa Belmonte JC (2006) Wnt/beta-catenin signaling regulates vertebrate limb regeneration. Genes Dev 20:3232-3237. CrossRef Medline

Kempfle JS, Turban JL, Edge AS (2016) Sox2 in the differentiation of cochlear progenitor cells. Sci Rep 6:23293. CrossRef Medline

Korrapati S, Roux I, Glowatzki E, Doetzlhofer A (2013) Notch signaling limits supporting cell plasticity in the hair cell-damaged early postnatal murine cochlea. PLoS One 8:e73276. CrossRef Medline

Ku YC, Renaud NA, Veile RA, Helms C, Voelker CC, Warchol ME, Lovett M (2014) The transcriptome of utricle hair cell regeneration in the avian inner ear. J Neurosci 34:3523-3535. CrossRef Medline

Kuo BR, Baldwin EM, Layman WS, Taketo MM, Zuo J (2015) In vivo cochlear hair cell generation and survival by coactivation of beta-catenin and Atoh1. J Neurosci 35:10786-10798. CrossRef Medline

Lin V, Golub JS, Nguyen TB, Hume CR, Oesterle EC, Stone JS (2011) Inhibition of Notch activity promotes nonmitotic regeneration of hair cells in the adult mouse utricles. J Neurosci 31:15329-15339. CrossRef Medline

Ma EY, Rubel EW, Raible DW (2008) Notch signaling regulates the extent of hair cell regeneration in the zebrafish lateral line. J Neurosci 28: 2261-2273. CrossRef Medline

Madisen L, Zwingman TA, Sunkin SM, Oh SW, Zariwala HA, Gu H, Ng LL, Palmiter RD, Hawrylycz MJ, Jones AR, Lein ES, Zeng H (2010) A robust and high-throughput Cre reporting and characterization system for the whole mouse brain. Nat Neurosci 13:133-140. CrossRef Medline

Matsui JI, Haque A, Huss D, Messana EP, Alosi JA, Roberson DW, Cotanche DA, Dickman JD, Warchol ME (2003) Caspase inhibitors promote vestibular hair cell survival and function after aminoglycoside treatment in vivo. J Neurosci 23:6111-6122. Medline

Meiteles LZ, Raphael Y (1994) Scar formation in the vestibular sensory epithelium after aminoglycoside toxicity. Hear Res 79:26-38. CrossRef Medline

Meyers JR, MacDonald RB, Duggan A, Lenzi D, Standaert DG, Corwin JT, Corey DP (2003) Lighting up the senses: FM1-43 loading of sensory cells through nonselective ion channels. J Neurosci 23:4054-4065. Medline

Mizutari K, Fujioka M, Hosoya M, Bramhall N, Okano HJ, Okano H, Edge AS (2013) Notch inhibition induces cochlear hair cell regeneration and recovery of hearing after acoustic trauma. Neuron 77:58-69. CrossRef Medline

Momiyama J, Hashimoto T, Matsubara A, Futai K, Namba A, Shinkawa H (2006) Leupeptin, a calpain inhibitor, protects inner ear hair cells from aminoglycoside ototoxicity. Tohoku J Exp Med 209:89-97. CrossRef Medline

Rosenblatt J, Raff MC, Cramer LP (2001) An epithelial cell destined for apoptosis signals its neighbors to extrude it by an actin- and myosindependent mechanism. Curr Biol 11:1847-1857. CrossRef Medline

Sato T, van Es JH, Snippert HJ, Stange DE, Vries RG, van den Born M, Barker N, Shroyer NF, van de Wetering M, Clevers H (2011) Paneth cells con- 
stitute the niche for Lgr5 stem cells in intestinal crypts. Nature 469: 415-418. CrossRef Medline

Shi F, Cheng YF, Wang XL, Edge AS (2010) Beta-catenin up-regulates Atoh1 expression in neural progenitor cells by interaction with an Atoh1 3' enhancer. J Biol Chem 285:392-400. CrossRef Medline

Shi F, Kempfle JS, Edge AS (2012) Wnt-responsive lgr5-expressing stem cells are hair cell progenitors in the cochlea. J Neurosci 32:9639-9648. CrossRef Medline

Shi F, Hu L, Edge AS (2013) Generation of hair cells in neonatal mice by beta-catenin overexpression in Lgr5-positive cochlear progenitors. Proc Natl Acad Sci U S A 110:13851-13856. CrossRef Medline

Shi F, Hu L, Jacques BE, Mulvaney JF, Dabdoub A, Edge AS (2014) betaCatenin is required for hair-cell differentiation in the cochlea. J Neurosci 34:6470-6479. CrossRef Medline

Silva-Vargas V, Lo Celso C, Giangreco A, Ofstad T, Prowse DM, Braun KM, Watt FM (2005) Beta-catenin and Hedgehog signal strength can specify number and location of hair follicles in adult epidermis without recruitment of bulge stem cells. Dev Cell 9:121-131. CrossRef Medline

Snyder CM, Rice AL, Estrella NL, Held A, Kandarian SC, Naya FJ (2013) MEF2A regulates the Gtl2-Dio3 microRNA mega-cluster to modulate WNT signaling in skeletal muscle regeneration. Development 140:31-42. CrossRef Medline
Sun G, Irvine KD (2014) Control of growth during regeneration. Curr Top Dev Biol 108:95-120. CrossRef Medline

Suzanne M, Steller H (2013) Shaping organisms with apoptosis. Cell Death Differ 20:669-675. CrossRef Medline

Wada H, Ghysen A, Asakawa K, Abe G, Ishitani T, Kawakami K (2013) Wnt/Dkk negative feedback regulates sensory organ size in zebrafish. Curr Biol 23:1559-1565. CrossRef Medline

Wang T, Chai R, Kim GS, Pham N, Jansson L, Nguyen DH, Kuo B, May LA, Zuo J, Cunningham LL, Cheng AG (2015) Lgr5 + cells regenerate hair cells via proliferation and direct transdifferentiation in damaged neonatal mouse utricle. Nat Commun 6:6613. CrossRef Medline

Warchol ME (2010) Cellular mechanisms of aminoglycoside ototoxicity. Curr Opin Otolaryngol Head Neck Surg 18:454-458. CrossRef Medline

Whyte JL, Smith AA, Helms JA (2012) Wnt signaling and injury repair. Cold Spring Harb Perspect Biol 4:a008078. Medline

Yang H, Gan J, Xie X, Deng M, Feng L, Chen X, Gao Z, Gan L (2010) Gfil-Cre knock-in mouse line: a tool for inner ear hair cell-specific gene deletion. Genesis 48:400-406. CrossRef Medline

Yokoyama H, Ogino H, Stoick-Cooper CL, Grainger RM, Moon RT (2007) Wnt/beta-catenin signaling has an essential role in the initiation of limb regeneration. Dev Biol 306:170-178. CrossRef Medline 